\title{
Science and Technology Indonesia
} e-ISSN:2580-4391 p-ISSN:2580-4405

Vol. 6, No. 3, July 2021

Research Paper

\section{Utilization of Activated Charcoal from Sawdust as an Antibiotic Adsorbent of Tetracycline Hydrochloride}

\author{
Gatut Ari Wardani ${ }^{1 *}$, Ega Maulana Qudsi ${ }^{1}$, Anindita Tri Kusuma Pratita ${ }^{1}$, Keni Idacahyati ${ }^{2}$, Estin Nofiyanti ${ }^{3}$ \\ ${ }^{1}$ Pharmacy Program, Bakti Tunas Husada Health Science College, Cilolohan Street No. 36, Tasikmalaya, West Java, Indonesia \\ ${ }^{2}$ Department of Pharmacology and Clinical Pharmacy, Bakti Tunas Husada Health Science College,Cilolohan Street No. 36, Tasikmalaya, West Java, Indonesia \\ ${ }^{3}$ Environmental Engineering Program, Faculty of Engineering, Muhammadiyah University of Tasikmalaya, Tamansari Street KM 2.5, Tasikmalaya, West Java, Indonesia \\ *Corresponding author: gatutariwardani@stikes-bth.ac.id
}

\begin{abstract}
The use of activated charcoal from sawdust as an adsorbent of tetracycline hydrochloride compounds has been successfully carried out. Sawdust activated charcoal was carbonized at $450^{\circ} \mathrm{C}$ for 40 minutes with a charcoal size of 100 mesh and activated using $\mathrm{H}_{3} \mathrm{PO}_{4}$ solution. The characteristics of active sawdust charcoal showed that water content, iodine adsorption, and methylene blue adsorption had met SNI 06-3730-1995 regarding technical activated charcoal. Testing the morphology of charcoal using a Scanning Electron Microscope showed that the charcoal pores were opened through the activation process. In the functional group analysis test using infrared spectroscopy, the active group contained in charcoal after being activated contained carbon atoms that were purer than sawdust. The adsorption process of tetracycline hydrochloride using sawdust activated charcoal is known to follow Ho or Pseudo second-order ( $K=0.0039 \mathrm{~g} / \mathrm{mg}$.min), while the adsorption isotherm follows the Langmuir equation, $K_{L}=0.0076 \mathrm{~L} / \mathrm{mg}$ and adsorption capacity amounting to $242.1307 \mathrm{mg} / \mathrm{g}$. Thermodynamically, the adsorption process occurs not spontaneously with a Gibbs free energy value of $120.8949 \mathrm{~kJ} / \mathrm{mol}$ and occurs by chemisorption.
\end{abstract}

Keywords

Chemisorption, Adsorption Kinetics, Adsorption Isotherms

Received: 22 March 2021, Accepted: 14 June 2021

https://doi.org/10.26554/sti.2021.6.3.181-188

\section{INTRODUGTION}

Environmental pollution is one of several factors that affect environmental quality. The rapid growth of the pharmaceutical industry will create new problems for the environment. It is indicated by the results of a research showing that many drugs, such as antibiotics, hormones, preservatives, and anesthetics are detected in lake, river, and groundwater (Miège et al., 2009).

Hospitals are one of the sources of water pollution besides lakes, rivers, and groundwater. Hospitals can have a negative impact where hospital wastewater contains carcinogenic and genotoxic drugs that can cause various diseases in the surrounding community, such as cancer and genetic disorders (Sharma et al., 2016). Besides that, it also produces drug residues, one of which is antibiotics. Antibiotics as antibacterial agents are widely used to treat and prevent diseases for humans and animals because antibiotics effectively inhibit and kill bacteria.

Antibiotics are drugs that are very important for treatment, such as transplants and chemotherapy. However, after years of use, the bacteria have become resistant to antibiotics. These resistant bacteria can be transmitted from animals to humans through the food chain or direct interaction. Thus, many various diseases caused by bacterial infections become resistant to treatment using antibiotic compounds. The resistance of these pathogenic bacteria creates problems for the patient and can also cause problems in the patient's environment (Kotsiftopoulos, 2017).

One type of antibiotic often used and found in surface water, especially hospital waste, is the tetracycline antibiotic (Pena et al., 2010). Pathogenic bacteria due to tetracycline resistance have also been found in sewage, rivers, ponds, and swimming pools (Nahar et al., 2019). Therefore, the elimination of tetracycline antibiotics (Figure 1) from water is essential to do.

Adsorption is the most common technique used in wastewater treatment to remove inorganic waste and organic waste (Zhang et al., 2017; Wang et al., 2018). The adsorption method is effective because of the advantages of simple operation, low cost, and low energy consumption (Yang et al., 2020). One of the adsorption methods that are often used is by using activated charcoal. Some of the ingredients that are used as activated charcoal include cassava peels (Ilaboya, 2013), 


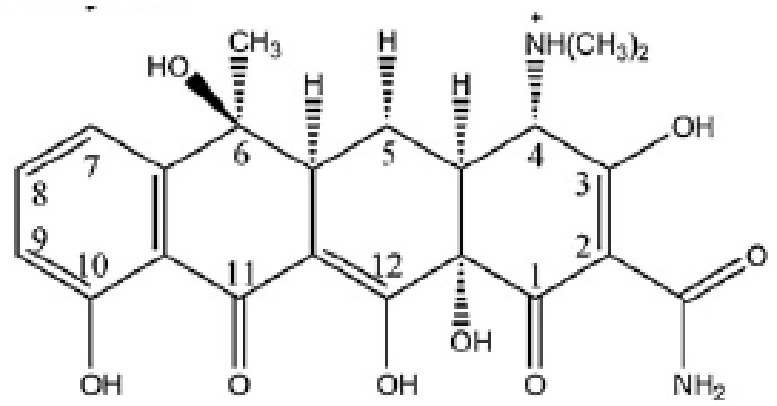

Figure 1. The Structure of Tetracycline Antibiotic (Gao et al., 2012)

corncob (Kaźmierczak et al., 2012; Rocha et al., 2015), banana peel (Ingole et al., 2016; Napitupulu et al., 2019; Karimibavani et al., 2020), straw (Sharaf and Hassan, 2013; Ramangkoon et al., 2016; Panhwar et al., 2019), eggshell (Ahmad et al., 2020), and coconut shell (Huang et al., 2015; Karunakara et al., 2015).

The removal of tetracycline in an aqueous solution includes using an organic metal skeleton derived from carbon- $\alpha$ $\mathrm{Fe} / \mathrm{Fe}_{3} \mathrm{C}$ as a magnetic adsorbent (Xiong et al., 2019), 3D film composites (Song et al., 2018), and carbon-based glyceryl material (Álvarez-Torrellas et al., 2016). This study studied the use of activated charcoal as an adsorbent for tetracycline hydrochloride antibiotics made from sawdust.

\section{EXPERIMENTAL SECTION}

\subsection{Materials}

The equipment used in this research included laboratory glassware, magnetic stirrer, 100 mesh sieve and filter paper, stopwatch, analytical balance, furnace, oven, Shimadzu UV-1800 spectrometer, Scanning Electron Microscope JEOL jsm-6360 LA, and Shimadzu IRPrestige-21 spectrophotometer. The chemicals used were analytical grade and without purification.

\subsection{Methods}

\subsubsection{Carbonization Process}

A total of $500 \mathrm{~g}$ of dry sawdust samples were hydrolyzed in a furnace at $450^{\circ} \mathrm{C}$ for 40 minutes. The charcoal formed was cooled in a desiccator and then weighed. Then, the yield percentage was determined. The charcoal was then crushed and then sieved with a 100 mesh sieve.

\subsubsection{Charcoal Activation}

The pyrolysis charcoal was immersed for 24 hours using a 15\% $\mathrm{H}_{3} \mathrm{PO}_{4}$ activator. The carbon yield was filtered and rinsed with water to neutral $\mathrm{pH}$, and then it was drained and put in an oven at $150^{\circ} \mathrm{C}$ for 3 hours.

\subsubsection{Testing the Characteristics of Activated Charcoal}

The procedure for analysis of activated charcoal refers to the SNI (Indonesian National Standard) 06-3730-1995 regarding technical activated charcoal. It was done by doing the testing in the form of water content, iodine adsorption, and methylene blue adsorption. Besides, charcoal morphological analysis was also carried out using Scanning Electron Microscope and functional group analysis using FTIR.

\subsubsection{Adsorption Kinetics Testing}

The $20 \mathrm{mg}$ of adsorbent was added to $100 \mathrm{ml}$ of $20 \mathrm{ppm}$ antibiotic solution. The mixture was stirred using a magnetic stirrer with a speed of $200 \mathrm{rpm}$ with a variation of contact times of $30,60,90,120$, and 150 minutes. Then, the antibiotic levels were measured using a UV-Vis spectrophotometer at a wavelength. The stories of the $\mathrm{UV}-\mathrm{V}$ is spectrophotometer results from the five variations of contact time were calculated and then entered into Santosa, Lagergren, and Ho's kinetic equation models.

\subsubsection{Adsorption Isotherm Testing}

The $20 \mathrm{mg}$ of adsorbent was added to $100 \mathrm{ml}$ of antibiotic solution with various concentrations used at 10, 50, 100, 150, and $200 \mathrm{ppm}$. Then, the mixture was stirred using a magnetic stirrer with a speed of $200 \mathrm{rpm}$ for 100 minutes and then it was filtered. Then, the filtrate was taken. The antibiotic absorbance was measured at the maximum wavelength. The $\mathrm{UV}-\mathrm{V}$ is spectrophotometer results from the five concentration variations were then counted and inputted into the Langmuir isotherm equation model and the Freundlich isotherm equation model.

\section{RESULT AND DISGUSSION}

\subsection{Results of Characterization of Activated Charcoal}

Carbonization is the initial stage for converting organic substances into carbon or carbon-containing residues through the pyrolysis process. The result of carbonization at $450^{\circ} \mathrm{C}$ for 40 minutes produced charcoal yield at $12 \%$. The carbonized charcoal was then activated using a solution of $15 \%$ phosphoric acid. A 15\% phosphoric acid solution was used as an activator because phosphoric acid is more environmentally friendly and economical among the various dehydrating agents used for chemical activation (Kumar and Jena, 2016). Also, phosphoric acid with a concentration of $15 \%$ can produce activated charcoal with the best characteristics and is according to SNI 06-37301995 (Sahara et al., 2017). Phosphoric acid increases the yield and decreases the reaction rate during the oxidation process to protect the charcoal from high temperatures (Hendra et al., 2015).

After activation with $15 \%$ phosphoric acid with a particle size of 100 mesh, the characteristics of activated charcoal were tested based on SNI 06-3730-1995. Testing the characterization of activated charcoal was carried out by determining the water content, adsorption of Methylene blue, and iodine adsorption. Water content testing was carried out to determine the water content in sawdust-activated charcoal after undergoing the carbonization and charcoal activation processes. The water content test provides an overview of the quality of the activated charcoal that is made. The greater the water content 


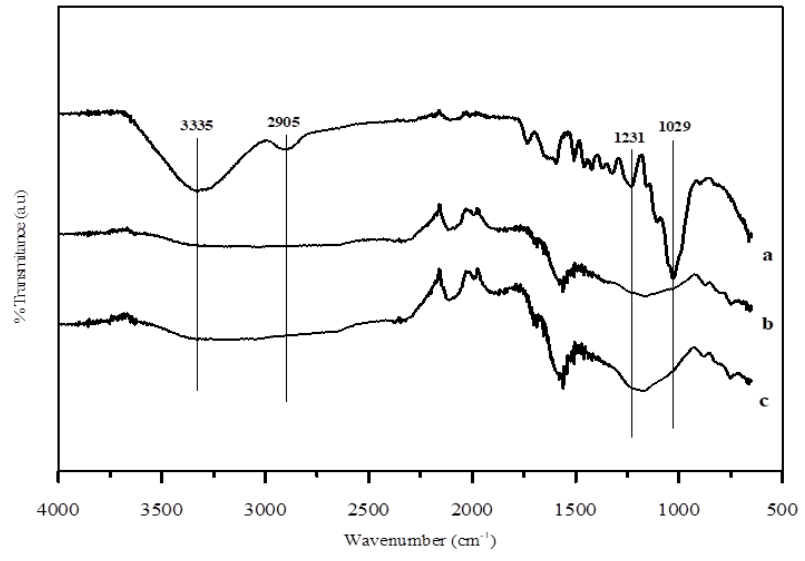

Figure 2. FTIR Results (a) Sawdust, (b) Charcoal Before Activation, (c) Charcoal After Activation

means that more water is absorbed in the activated charcoal. This water can cover the pores of activated charcoal to decrease the adsorbent's adsorption capacity.

The methylene blue adsorption test can be related to the surface area of activated charcoal (Jawad et al., 2016). The greater the adsorption of activated charcoal against methylene blue, it is expected that it will also have a large adsorption capacity when applied to the sample. Activated charcoal can absorb iodine very well. Therefore, the iodine adsorption number can be used to predict the total surface area of activated charcoal (Madu et al., 2013). Methylene blue adsorption and iodine adsorption tests were carried out to predict the surface area of the activated charcoal formed, so that effective activated charcoal could be obtained to be used for adsorption. The results of characterization of activated charcoal from sawdust produced (Table 1) follow SNI 06-3730-1995.

Analysis of functional groups on activated charcoal was carried out using FTIR. This analysis compared by looking at the functional groups on the charcoal before the activation process and the functional groups on the charcoal after the activation process with $15 \%$ phosphoric acid. Analysis of activated carbon before and after activation by FTIR can be seen in Figure 2.

Based on Figure 2, it can be seen that in the sawdust (Figure 2.a), there is a broad absorption band in the $3335 \mathrm{~cm}^{-1}$ area, which indicates the presence of hydrogen lignin bonds, the absorption band in the $2905 \mathrm{~cm}^{-1}$ region, which means the presence of alkane groups (-CH), the area $2107 \mathrm{~cm}^{-1}$ of the alkynes group $(\mathrm{C} \equiv \mathrm{C})$, the site of $1594 \mathrm{~cm}^{-1}$ where there is a $\mathrm{C}=\mathrm{C}$ bond of lignin and the absorption area of $1231 \mathrm{~cm}^{-1}$ where there is a cellulose C-O-C bond (Poletto et al., 2012) and the $\mathrm{C}-\mathrm{N}$ group in the absorption area of $1029 \mathrm{~cm}^{-1}$. Some of the absorption bands of lignin, hemicellulose, and cellulose in sawdust were successfully removed by a charcoal process. FTIR spectra on activated charcoal can confirm it before activation (Figure 2.b), which does not show that there is absorption on the hydroxyl group $\left(3335 \mathrm{~cm}^{-1}\right)$, the alkane group (2905

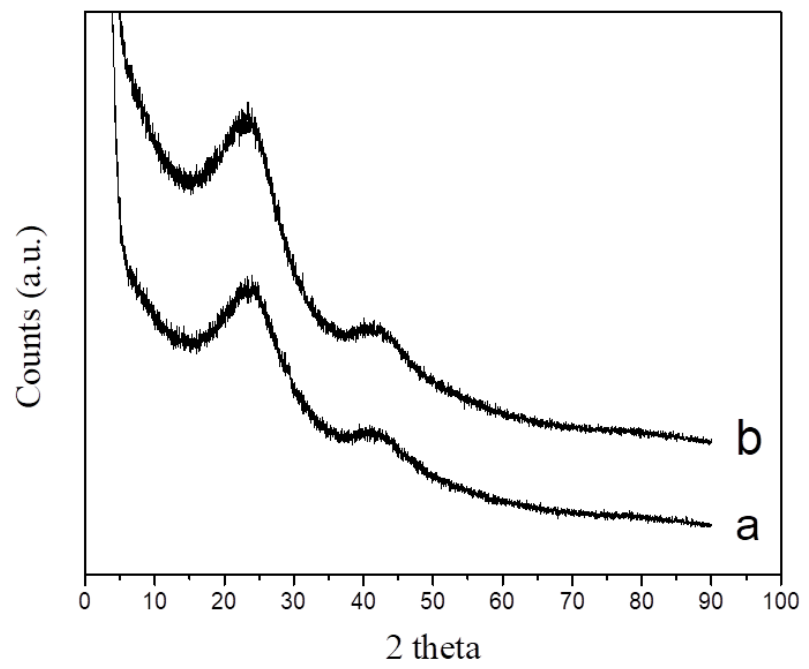

Figure 3. Characterization Results using XRD (a) Before and (b) After Activation

$\left.\mathrm{cm}^{-1}\right)$, and the $\mathrm{C}-\mathrm{N}$ group $\left(1029 \mathrm{~cm}^{-1}\right)$. This indicates that the charring process's goal, namely removing organic functional groups, has been successfully carried out. Changes in the structural framework were also seen in the different fingerprint areas between the sawdust and charcoal. The functional groups on the pre-activated charcoal (Figure 2.b) and the activated charcoal (Figure 2.c) did not show any difference except for peak shifts. There was no difference in functional groups between the charcoal before activation and after the activation process. The $15 \% \mathrm{H}_{3} \mathrm{PO}_{4}$ solution as an activator only functioned to enlarge the pores in the charcoal.

The activated charcoal formed had an amorphous particle structure by characterization results using XRD (Figure 3). Based on XRD spectra, it can be seen that the charcoal activation process causes a shift towards a smaller angle. The shift in the angle indicates an increase in the distance between the layers (Shi et al., 2019).

The morphology of activated charcoal was analyzed using SEM to see the inactivated and activated charcoal pore sizes. Based on the analysis using SEM (Figure 4), the pores of activated charcoal after being activated using $15 \%$ phosphoric acid are more open than before being activated. Charcoal cavities and pores are also formed due to heat during the carbonization process, which causes the decomposition process of organic compounds, such as lignin, holocellulose, and pentosane in sawdust activated charcoal. The carbonization process generates many volatile materials to evaporate to form many active lattices (pores). Phosphoric acid reacts with alcohol groups remaining in charcoal at low temperatures to form organic phosphates, which are unstable and quickly degraded in acidic or neutral media (Wu et al., 2018). The volume occupied by organic phosphate, which is then degraded, can result in a larger volume and pore size. 
Table 1. Results of the Characteristics of Sawdust Activated Charcoal

\begin{tabular}{ccc}
\hline Testing & SNI 06-3730-1995 & Results \\
\hline Water content & Max 15\% & $1.69 \%$ \\
Methylene Blue Adsorption & Min $120 \mathrm{mg} / \mathrm{g}$ & $235.3026 \mathrm{mg} / \mathrm{g}$ \\
Iodine Adsorption & Min 750 mg/g & $995.3211 \mathrm{mg} / \mathrm{g}$ \\
\hline
\end{tabular}

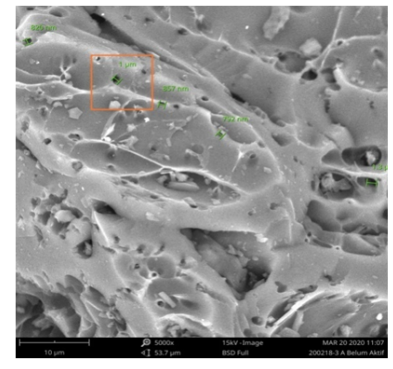

(a)

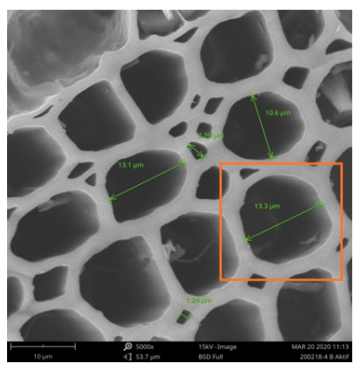

(b)

Figure 4. SEM Results of Charcoal (a) Before and (b) After Activation at 5000x Magnification

\subsection{Results of Activated Charcoal Adsorption on Tetracy- cline Hydrochloride Antibiotics}

The adsorption results of tetracycline hydrochloride antibiotic solution using sawdust activated charcoal with various contact time variations are presented in Figure 5. Measurement of the concentration of tetracycline hydrochloride using UV Vis spectrophotometry was at a wave of $276 \mathrm{~nm}$. The optimum time during the adsorption process for tetracyclic hydrochloride occurred at 90 minutes. At 120 and 150 minutes, the adsorption process of activated charcoal against tetracycline hydrochloride decreased. The decrease in adsorption occurred because the activated charcoal had saturated bonds with tetracycline hydrochloride or the active side that had been maximally filled did not absorb more tetracycline hydrochloride. The kinetics study was conducted to determine the adsorption kinetics model that occurred. The model studied in this study's adsorption process uses the Santosa kinetics equation, the pseudo-first-order (PFO) kinetics model (Lagergren kinetics), and the pseudosecond-order (PSO) kinetics model (Ho kinetics). The Santosa kinetics model can be calculated by equation 1 (Santosa et al., 2007), while the PFO and PSO kinetics models can be calculated based on equations 2 and 3, respectively (Santosa et al., 2007), while the PFO and PSO kinetics models can be calculated based on equations 2 and 3, respectively (Siregar et al., 2021).

$$
\frac{\ln \left(\frac{C_{A 0}}{C_{A}}\right)}{C_{A}}=k_{s} \frac{t}{C_{A}}+Q
$$

Where $\mathrm{C}_{A 0}$ is the initial concentration; $\mathrm{C}_{A}$ is the $\mathrm{A}$ species concentration in solution; $k_{s}$ is the adsorption rate constant for Santosa; $t$ is the adsorption time; $Q$ is sorption-desorption

constant

$$
\begin{aligned}
& \log \left(Q_{e}-Q_{t}\right)=\log Q_{e}-\left(\frac{k_{1}}{2.303}\right) t \\
& \frac{1}{Q_{t}}=\frac{1}{k_{2} Q_{e}^{2}}+\frac{1}{Q_{e}}
\end{aligned}
$$

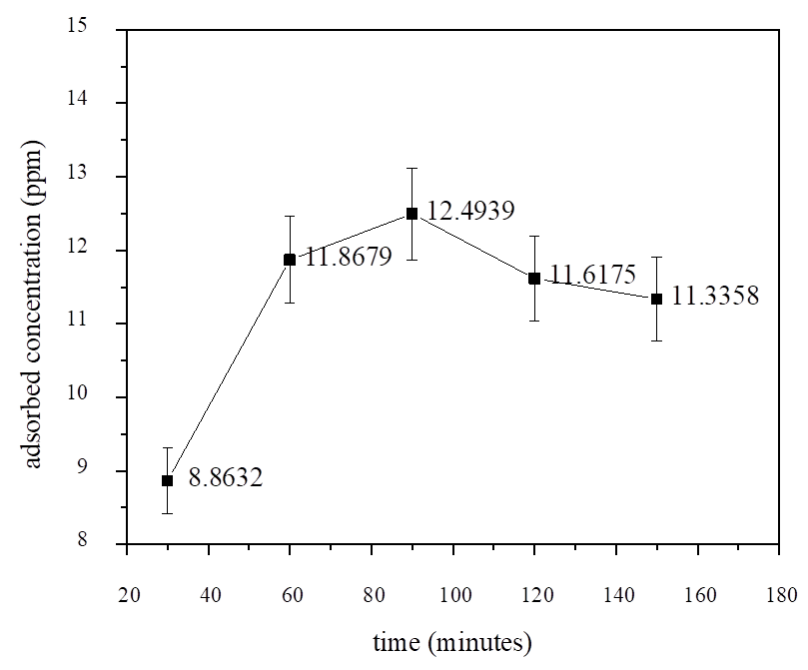

Figure 5. Tetracycline Hydrochloride Adsorption Results with Variation in Contact Time

Where $Q_{e}$ is the adsorption capacity $(\mathrm{mg} / \mathrm{g}) ; Q_{t}$ is the adsorption capacity at $t(\mathrm{mg} / \mathrm{g}) ; t$ is the adsorption time (minutes); $k_{1}$ is the adsorption rate constant for PFO $\left(\mathrm{min}^{-1}\right)$; and $k_{2}$ is the adsorption rate constant for PSO (g/mg.min). The graph of the adsorption kinetics analysis results for the three models used is presented in Table 2.

Based on Table 2 regarding the calculation of the adsorption kinetics parameters of the three adsorption kinetics models studied, the Ho kinetics or PSO kinetics model provides the best linearity value $\left(\mathrm{R}^{2} \approx 1\right)$ compared to the Santosa and Lagergren (PFO) kinetics models. Thus, tetracycline hydrochloride antibiotic solution's adsorption process more closely follows the Ho pseudo-second-order kinetics model. An adsorption rate constant of $0.0039 \mathrm{~g} / \mathrm{mg}$.min means that 0.0039 grams of the adsorbent can adsorb $1.0 \mathrm{mg}$ of adsorbate in 1 minute. It implies that the factors that influence the tetracycline hydrochloride antibiotic solution's adsorption rate are the adsorbent's concentration and active site. 
Table 2. Adsorption Kinetics Parameters of Santosa, PFO and PSO

\begin{tabular}{ccccc}
\hline \multirow{2}{*}{ Kinetics Model } & \multicolumn{4}{c}{ Parameter } \\
& $\mathrm{Qe}_{\text {exp }}$ & $\mathrm{Qe}_{\text {calc }}$ & $R^{2}$ & $k$ \\
\hline Santosa & - & - & 0.316 & $0.0028 \mathrm{~min}^{-1}$ \\
PFO (Lagergreen) & $100 \mathrm{mg} / \mathrm{g}$ & $50.015 \mathrm{mg} / \mathrm{g}$ & 0.251 & $-0.0007 \mathrm{~min}^{-1}$ \\
PSO (Ho) & $100 \mathrm{mg} / \mathrm{g}$ & $60.241 \mathrm{mg} / \mathrm{g}$ & 0.985 & $0.0039 \mathrm{~g} / \mathrm{mg} . \mathrm{min}$ \\
\hline
\end{tabular}

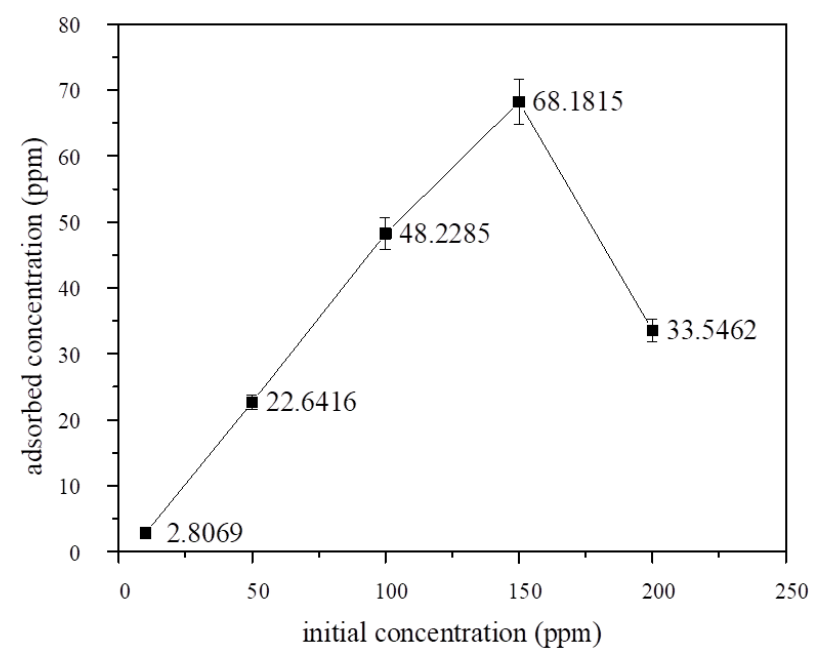

Figure 6. Effect of Initial Concentration on Tetracycline Hydrochloride Adsorption

The adsorption results of tetracycline hydrochloride antibiotic solution using sawdust activated charcoal for testing the adsorption isotherm using various concentrations of 10 , 50, 100, 150, 200 ppm are presented in Figure 6. Based on this figure, it is known that the initial concentration of tetracycline hydrochloride that can be adsorbed is the maximum of $150 \mathrm{ppm}$. The parameters of the Freundlich and Langmuir isotherms are presented in Table 3. Both of them can be calculated with equations 4 (Freundlich) and 5 (Langmuir). Freundlich isotherm is usually used to describe adsorption events on heterogeneous surfaces, whereas Langmuir isotherm occurs when adsorption occurs on a monolayer surface (Dada, 2012).

$$
\begin{aligned}
& \log Q_{e}=\log \mathrm{K}_{F}+1 / n \log \mathrm{C}_{e} \\
& \frac{1}{\mathrm{qe}}=\frac{1}{Q_{m}}+\frac{1}{Q_{m} \mathrm{~K}_{L} \mathrm{C}_{e}}
\end{aligned}
$$

Where $K_{f}$ is Freundlich isotherm constant $(\mathrm{mg} / \mathrm{g}) ; n$ is adsorption intensity; $\mathrm{C}_{e}$ is the aquilibrium concentration of adsorbate $(\mathrm{mg} / \mathrm{L}) ; Q_{e}$ is the amount of metal adsorbed per gram of the adsorbent at equilibrium $(\mathrm{mg} / \mathrm{g}) ; K_{L}$ is Langmuir isotherm constant $(\mathrm{L} / \mathrm{mg}) ; Q_{m}$ is maximum monolayer coverage capacity $(\mathrm{L} / \mathrm{mg}) ; \mathrm{q}_{e}$ is the amount of metal adsorbed per gram of the adsorbent at equilibrium $(\mathrm{mg} / \mathrm{g})$.
Table 3. Parameters of Freundlich and Langmuir Isotherms

\begin{tabular}{ccc}
\hline Isotherm model & Parameters & Value \\
\hline & $R^{2}$ & 0.8694 \\
Freundlich & $K_{F}$ & $4.2092 \mathrm{~L} / \mathrm{mg}$ \\
& $n$ & 1.0212 \\
& $\Delta G^{0}$ & $-3.5609 \mathrm{~kJ} / \mathrm{mol}$ \\
& $R^{2}$ & 0.9718 \\
Langmuir & $K_{L}$ & $0.0076 \mathrm{~L} / \mathrm{mg}$ \\
& $Q_{m}$ & $242.1308 \mathrm{mg} / \mathrm{g}$ \\
& $\Delta G^{0}$ & $120.8949 \mathrm{~kJ} / \mathrm{mol}$ \\
\hline
\end{tabular}

From Table 3, it can see that the adsorption of tetracycline hydrochloride antibiotic solution using sawdust activated charcoal is closer to the Langmuir adsorption isotherm model. It can be proven by the value of the relation coefficient $\left(\mathrm{R}^{2}\right)$, which is closer to 1 compared to the Freundlich model. On the surface, the active sawdust charcoal adsorbent is homogeneous and the adsorbate is adsorbed in a single (monolayer) form. Langmuir model illustrates that there are a certain number of active sites that are proportional to the surface area on the adsorbent's surface. On each active site, there is only one adsorbable molecule. Langmuir adsorption isotherm is usually used to describe the physisorption adsorption, whereas Freundlich model describes the occurrence of chemisorption adsorption.

In chemisorption, tetracycline hydrochloride as an adsorbate forms covalent bonds with adsorbents and has a large adsorption heat. This matter is different from the physisorption event, which only has a low adsorption heat, and the adsorbate is only attracted by the adsorbent through weak Van der Waals forces as shown in Figure 7. The difference between physisorption and chemisorption can be determined more clearly by determining the enthalpy $\left(\Delta H^{0}\right)$ and Gibbs free energy $\left(\Delta G^{0}\right)$. Physisorption occurs when the $\Delta H^{0}$ value is between -2.1 and $-20.9 \mathrm{~kJ} / \mathrm{mol}$, or the $\Delta G^{0}$ value is between 0 and $-20 \mathrm{~kJ} / \mathrm{mol}$, while chemisorption adsorption can occur if the $\Delta H^{0}$ value is between -80 and $-200 \mathrm{~kJ} / \mathrm{mol}$ or $\Delta G^{0}$ value is between -80 and $-400 \mathrm{~kJ} / \mathrm{mol}$ (Húmpola et al., 2013).

The Gibbs free energy can be determined by equation 6 .

$$
\Delta G^{0}=R T \ln K
$$

Where $\Delta G^{0}$ is Gibbs free energy $(\mathrm{kJ} / \mathrm{mol}) ; R$ is the gas constant $(8.314 \mathrm{~J} / \mathrm{mol} . \mathrm{K}) ; T$ is temperature $(K) ; K$ is the Langmuir 
Table 4. Adsorption of Tetracycline Hydrochloride using Several Adsorbents

\begin{tabular}{ccc}
\hline Adsorbent & Adsorption capacity & References \\
\hline Ball milled bio char & $84.54 \mathrm{mg} / \mathrm{g}$ & (Xiang et al., 2020) \\
Magnetic carbon-coated & $769.43 \mathrm{mg} / \mathrm{g}$ & (Yang et al., 2020) \\
cobalt oxide nanoparticles & $113.6 \mathrm{mg} / \mathrm{g}$ & (Shi et al., 2016) \\
$\mathrm{Cu}_{2} \mathrm{O}-\mathrm{TiO}_{2}-\mathrm{Pal}$ & $364.37 \mathrm{mg} / \mathrm{g}$ & (Xiong et al., 2019) \\
$\mathrm{MWCNT} / \mathrm{MIL}^{-53}(\mathrm{Fe})$ & $8.37 \mathrm{mg} / \mathrm{g}$ & (Chen et al., 2016) \\
Rice hulk ash & $141.4427 \mathrm{mg} / \mathrm{g}$ & (Miao et al., 2019) \\
Magnetic graphene oxide & $322.43 \mathrm{mg} / \mathrm{g}$ & (Ghadim et al., 2013) \\
Graphene oxide & $897.6 \mathrm{mg} / \mathrm{g}$ & (Zhang et al., 2015) \\
Petroleum coke derived ACs & $53.26 \mathrm{mg} / \mathrm{g}$ & (Zhang et al., 2019) \\
Cu-immobilized alginate & $45.39 \mathrm{mg} / \mathrm{g}$ & (Li et al., 2017b) \\
Iron-incorporated hydroxyapatite & $257.07 \mathrm{mg} / \mathrm{g}$ & (Liu et al., 2015) \\
$\mathrm{Fe}_{3} \mathrm{O}_{4} /$ PAN composite NFs & $1911.8 \mathrm{mg} / \mathrm{g}$ & (Liu et al., 2020b) \\
A garlic skin-derived & $230.69 \mathrm{mg} / \mathrm{g}$ & (Ali et al., 2018) \\
porous biomass carbon & $166 \mathrm{mg} / \mathrm{g}$ & (Li et al., 2017a) \\
NaY zeolite straw ash & $157.38 \mathrm{mg} / \mathrm{g}$ & (Liu et al., 2020a) \\
Magnetic microsphere & $242.1308 \mathrm{mg} / \mathrm{g}$ & This research \\
HSBB600 & & \\
Sawdust activated charcoal & &
\end{tabular}

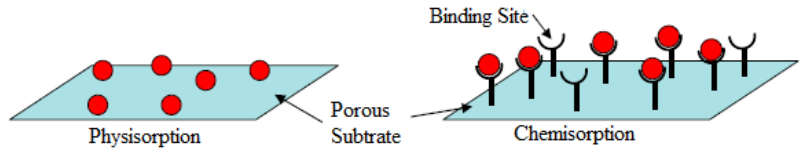

Figure 7. Schematic of the Physisorption and Chemisorption Events (Berger and Bhown, 2011)

or Freundlich (L/mg) adsorption rate (Húmpola et al., 2013). Based on equation 6 , the value of $\Delta G^{0}$ in the tetracycline hydrochloride adsorption process by sawdust activated charcoal is $120.8949 \mathrm{~kJ} / \mathrm{mol}$. Gibbs free energy is in the range of 80 to $400 \mathrm{~kJ} / \mathrm{mol}$, indicating that the adsorption process that occurs is chemisorption. A positive value at $\Delta G^{0}$ indicates that the adsorption process is not spontaneous.

The entropy and enthalpy values can be obtained by converting equation 6 into a linear equation as in equation 7 .

$$
\ln K=\frac{\Delta S}{R}-\frac{\Delta H}{R T}
$$

Where $\Delta S$ is the system entropy $(\mathrm{J} / \mathrm{mol} . \mathrm{K})$ and $\Delta H$ is the system enthalpy $(\mathrm{kJ} / \mathrm{mol})$. The entropy and enthalpy values can be obtained by plotting $\ln K$ against $1 / \mathrm{T}$ into a linear regression equation. The slope and intercept values of the equation show the enthalpy and entropy values, respectively. In this study, the enthalpy and entropy values could not be determined in the adsorption process of tetracycline hydrochloride by activated charcoal from sawdust because there was no variation in temperature. Tetracycline hydrochloride adsorption can also be carried out using other types of adsorbents as shown in Table 4 .

\section{CONCLUSIONS}

The characteristics of sawdust activated charcoal showed moisture content, iodine adsorption, and methylene blue adsorption, namely $1.69 \%, 995.3211 \mathrm{mg} / \mathrm{g}$, and $235.3067 \mathrm{mg} / \mathrm{g}$, respectively. All the following characteristics followed SNI 06-3730-1995 regarding technical activated charcoal, so that the activation process succeeded in expanding the pore surface from $1 \mu \mathrm{m}$ to $13 \mu \mathrm{m}$. The kinetics test of active sawdust charcoal adsorption against tetracycline hydrochloride antibiotics followed the Ho kinetics equation (PSO) with $\mathrm{R}^{2}=0.985$, $\mathrm{K}$ value of $0.0039 \mathrm{~g} / \mathrm{mg}$.min, and $q_{e}$ of $60.241 \mathrm{mg} / \mathrm{g}$. The test isotherm of active sawdust charcoal adsorption more closely followed the Langmuir equation model with $\mathrm{R}^{2}=0.972$, the $K_{L}$ value of $0.0076 \mathrm{~L} / \mathrm{mg}$, and adsorption capacity 242.1308 $\mathrm{mg} / \mathrm{g}$. Gibbs's free energy from the adsorption process was positive, indicating that the adsorption process did not spontaneously occur.

\section{ACKNOWLEDGEMENT}

Our gratitude goes to the research and service center for the community of STIKes Bakti Tunas Husada Tasikmalaya, which has assisted in the form of research funds by research contract number $17 \mathrm{a} / \mathrm{i}$-STIKes/XI/2019, so that this research can be completed properly.

\section{REFERENCES}

Ahmad, A., D. Jini, M. Aravind, C. Parvathiraja, R. Ali, M. Z. Kiyani, and A. Alothman (2020). A novel study on synthesis of egg shell based activated carbon for degradation of methylene blue via photocatalysis. Arabian Journal of Chemistry, 13(12); 8717-8722 
Ali, M. M., M. Ahmed, and B. Hameed (2018). NaY zeolite from wheat (Triticum aestivum L.) straw ash used for the adsorption of tetracycline. Journal of Cleaner Production, 172; 602-608

Álvarez-Torrellas, S., A. Rodríguez, G. Ovejero, and J. García (2016). Comparative adsorption performance of ibuprofen and tetracycline from aqueous solution by carbonaceous materials. Chemical Engineering Journal, 283; 936-947

Berger, A. H. and A. S. Bhown (2011). Comparing physisorption and chemisorption solid sorbents for use separating $\mathrm{CO}_{2}$ from flue gas using temperature swing adsorption. Energy Procedia, 4; 562-567

Chen, Y., F. Wang, L. Duan, H. Yang, and J. Gao (2016). Tetracycline adsorption onto rice husk ash, an agricultural waste: Its kinetic and thermodynamic studies. Journal of Molecular Liquids, 222; 487-494

Dada, A. (2012). Langmuir, Freundlich, Temkin and Dubinin-Radushkevich Isotherms Studies of Equilibrium Sorption of $\mathrm{Zn}^{2+}$ Unto Phosphoric Acid Modified Rice Husk. IOSR Journal of Applied Chemistry, 3(1); 38-45

Gao, Y., Y. Li, L. Zhang, H. Huang, J. Hu, S. M. Shah, and X. Su (2012). Adsorption and removal of tetracycline antibiotics from aqueous solution by graphene oxide. Journal of Colloid and Interface Science, 368(1); 540-546

Ghadim, E. E., F. Manouchehri, G. Soleimani, H. Hosseini, S. Kimiagar, and S. Nafisi (2013). Adsorption Properties of Tetracycline onto Graphene Oxide: Equilibrium, Kinetic and Thermodynamic Studies. PLoS ONE, 8(11); 1-9

Hendra, D., A. Wulanawati, K. Gustina, H. Wibisono, et al. (2015). Utilization of activated charcoal made of bintaro's fruit shell (Cerbera manghas) as an adsorbent to improve water quality. Jurnal Penelitian Hasil Hutan, 33(3); 181-191

Huang, P.-H., H.-H. Cheng, and S.-H. Lin (2015). Adsorption of Carbon Dioxide onto Activated Carbon Prepared from Coconut Shells. Journal of Chemistry, 2015; 1-10

Húmpola, P. D., H. S. Odetti, A. E. Fertitta, and J. L. Vicente (2013). Thermodynamic Analysis of Adsorption Models of Phenol in Liquid Phase on Different Activated Carbons. Journal of the Chilean Chemical Society, 58(1); 1541-1544

Ilaboya, I. (2013). Performance of Activated Carbon from Cassava Peels for the Treatment of Effluent Wastewater. Iranica Journal of Energy and Environment, 4(4); 361-375

Ingole, R. S., D. H. Lataye, and P. T. Dhorabe (2016). Adsorption of phenol onto Banana Peels Activated Carbon. KSCE Journal of Civil Engineering, 21; 1-11

Jawad, A. H., R. A. Rashid, M. A. M. Ishak, and L. D. Wilson (2016). Adsorption of methylene blue onto activated carbon developed from biomass waste by $\mathrm{H}_{2} \mathrm{SO}_{4}$ activation: kinetic, equilibrium and thermodynamic studies. Desalination and Water Treatment, 57(52); 1-13

Karimibavani, B., A. B. Sengul, and E. Asmatulu (2020). Converting briquettes of orange and banana peels into carbonaceous materials for activated sustainable carbon and fuel sources. Energy, Ecology and Environment, 5(3); 161-170

Karunakara, N., K. S. Kumara, I. Yashodhara, B. Sahoo,
J. Gaware, B. Sapra, and Y. Mayya (2015). Evaluation of radon adsorption characteristics of a coconut shell-based activated charcoal system for radon and thoron removal applications. Journal of Environmental Radioactivity, 142; 87-95

Kaźmierczak, J., P. Nowicki, and R. Pietrzak (2012). Sorption properties of activated carbons obtained from corn cobs by chemical and physical activation. Adsorption, 19; 273-281

Kotsiftopoulos, C. (2017). The rational use of antibiotics medicine. Archivos De Medicina, 2(4); 36

Kumar, A. and H. M. Jena (2016). Preparation and characterization of high surface area activated carbon from Fox nut ( Euryale ferox ) shell by chemical activation with $\mathrm{H}_{3} \mathrm{PO}_{4}$. Results in Physics, 6; 651-658

Li, B., J. Ma, L. Zhou, and Y. Qiu (2017a). Magnetic microsphere to remove tetracycline from water: Adsorption, $\mathrm{H}_{2} \mathrm{O}_{2}$ oxidation and regeneration. Chemical Engineering Journal, 330; 191-201

Li, Y., S. Wang, Y. Zhang, R. Han, and W. Wei (2017b). Enhanced tetracycline adsorption onto hydroxyapatite by Fe(III) incorporation. Journal of Molecular Liquids, 247; 171-181

Liu, H., G. Xu, and G. Li (2020a). The characteristics of pharmaceutical sludge-derived biochar and its application for the adsorption of tetracycline. Science of The Total Environment, $747 ; 141492$

Liu, Q., L.-B. Zhong, Q.-B. Zhao, C. Frear, and Y.-M. Zheng (2015). Synthesis of $\mathrm{Fe}_{3} \mathrm{O}_{4} /$ Polyacrylonitrile Composite Electrospun Nanofiber Mat for Effective Adsorption of Tetracycline. ACS Applied Materials \&̊ Interfaces, 7(27); 1457314583

Liu, S., M. Pan, Z. Feng, Y. Qin, Y. Wang, L. Tan, and T. Sun (2020b). Ultra-high adsorption of tetracycline antibiotics on garlic skin-derived porous biomass carbon with high surface area. New Journal of Chemistry, 44(3); 1097-1106

Madu, P., L. Lajide, et al. (2013). Physicochemical characteristics of activated charcoal derived from melon seed husk. Journal of Chemical and Pharmaceutical Research, 5(5); 94-98

Miao, J., F. Wang, Y. Chen, Y. Zhu, Y. Zhou, and S. Zhang (2019). The adsorption performance of tetracyclines on magnetic graphene oxide: A novel antibiotics absorbent. $A p$ plied Surface Science, 475; 549-558

Miège, C., J. Choubert, L. Ribeiro, M. Eusèbe, and M. Coquery (2009). Fate of pharmaceuticals and personal care products in wastewater treatment plants - Conception of a database and first results. Environmental Pollution, 157(5); 1721-1726

Nahar, A., M. A. Islam, M. A. Sobur, M. J. Hossain, S. B. Zaman, M. B. Rahman, S. L. Kabir, and M. T. Rahman (2019). Detection of tetracycline resistant E. coli and Salmonella spp. in sewage, river, pond and swimming pool in Mymensingh, Bangladesh. African Journal of Microbiology Research, 13(25); 382-387

Napitupulu, M., M. Al-Gifary, and D. K. Walanda (2019). Adsorption of Cd (II) by Carbon Prepared from Peels and Stems of Kepok Banana (Musa Paradisiaca Formatypica). Cellulose Chemistry and Technology, 53(3-4); 387-394 
Panhwar, İ., A. A. Babar, S. Qureshi, S. A. Memon, and M. Araİn (2019). Utilization of biomass (Rice straw) to produce activated charcoal through single stage pyrolysis process. Journal of International Environmental Application and Science, 14(1); 1-6

Pena, A., M. Paulo, L. J. G. Silva, M. Seifrtová, C. M. Lino, and P. Solich (2010). Tetracycline antibiotics in hospital and municipal wastewaters: a pilot study in Portugal. Analytical and Bioanalytical Chemistry, 396(8); 2929-2936

Poletto, M., A. J. Zattera, and R. M. Santana (2012). Structural differences between wood species: evidence from chemical composition, FTIR spectroscopy, and thermogravimetric analysis. Journal of Applied Polymer Science, 126(5); 1-8

Ramangkoon, S., C. Saenjum, and B. Sirithunyalug (2016). Preparation of rice straw activated charcoal by 2 -step $\mathrm{H}_{3} \mathrm{PO}_{4}$ activation. International Journal of Pharmacy and Pharmaceutical Sciences, 8(4); 218-221

Rocha, P. D., A. S. Franca, and L. S. Oliveira (2015). Batch and Column Studies of Phenol Adsorption by an Activated Carbon Based on Acid Treatment of Corn Cobs. International Journal of Engineering and Technology, 7(6); 459-464

Sahara, E., N. K. Dahliani, and I. B. P. Manuaba (2017). Pembuatan dan Karakterisasi Arang Aktif dari Batang Tanaman Gumitir (Tagetes Erecta) dengan Aktivator NaOH. Jurnal Kimia, 11(1); 1-9

Santosa, S. J., D. Siswanta, A. Kurniawan, and W. H. Rahmanto (2007). Hybrid of chitin and humic acid as high performance sorbent for Ni(II). Surface Science, 601(22); 5155-5161

Sharaf, G. and H. Hassan (2013). Removal of copper ions from aqueous solution using silica derived from rice straw: comparison with activated charcoal. International Journal of Environmental Science and Technology, 11(6); 1581-1590

Sharma, V. K., N. Johnson, L. Cizmas, T. J. McDonald, and H. Kim (2016). A review of the influence of treatment strategies on antibiotic resistant bacteria and antibiotic resistance genes. Chemosphere, 150; 702-714

Shi, Y., G. Liu, L. Wang, and H. Zhang (2019). Activated carbons derived from hydrothermal impregnation of sucrose with phosphoric acid: remarkable adsorbents for sulfamethoxazole removal. RSC Advances, 9(31); 1784117851

Shi, Y., Z. Yang, B. Wang, H. An, Z. Chen, and H. Cui (2016). Adsorption and photocatalytic degradation of tetracycline hydrochloride using a palygorskite-supported $\mathrm{Cu}_{2} \mathrm{O}-\mathrm{TiO}_{2}$ composite. Applied Clay Science, 119; 311-320
Siregar, P. M. S. B. N., N. R. Palapa, A. Wijaya, E. S. Fitri, and A. Lesbani (2021). Structural Stability of Ni/Al Layered Double Hydroxide Supported on Graphite and Biochar Toward Adsorption of Congo Red. Science and Technology Indonesia, 6(2); 85-95

Song, Z., Y.-L. Ma, C.-E. Li, and M. Xu (2018). Removal of tetracycline residue from pharmaceutical wastewater by using 3D composite film. Chemical Engineering Journal, 348; 898-907

Wang, R.-Z., D.-L. Huang, Y.-G. Liu, C. Zhang, C. Lai, G.M. Zeng, M. Cheng, X.-M. Gong, J. Wan, and H. Luo (2018). Investigating the adsorption behavior and the relative distribution of $\mathrm{Cd}^{2+}$ sorption mechanisms on biochars by different feedstock. Bioresource Technology, 261; 265-271

Wu, H., Z. Li, and H. Liu (2018). Development of carbon adsorbents with high surface acidity and basicity from polyhydric alcohols with phosphoric acid activation for $\mathrm{Ni}$ (II) removal. Chemosphere, 206; 115-121

Xiang, W., Y. Wan, X. Zhang, Z. Tan, T. Xia, Y. Zheng, and B. Gao (2020). Adsorption of tetracycline hydrochloride onto ball-milled biochar: Governing factors and mechanisms. Chemosphere, 255; 127057

Xiong, W., Z. Zeng, G. Zeng, Z. Yang, R. Xiao, X. Li, J. Cao, C. Zhou, H. Chen, M. Jia, Y. Yang, W. Wang, and X. Tang (2019). Metal-organic frameworks derived magnetic carbon$\alpha \mathrm{Fe} / \mathrm{Fe}_{3} \mathrm{C}$ composites as a highly effective adsorbent for tetracycline removal from aqueous solution. Chemical Engineering Journal, 374; 91-99

Yang, G., Q. Gao, S. Yang, S. Yin, X. Cai, X. Yu, S. Zhang, and Y. Fang (2020). Strong adsorption of tetracycline hydrochloride on magnetic carbon-coated cobalt oxide nanoparticles. Chemosphere, 239; 124831

Zhang, D., J. Yin, J. Zhao, H. Zhu, and C. Wang (2015). Adsorption and removal of tetracycline from water by petroleum coke-derived highly porous activated carbon. Journal of Environmental Chemical Engineering, 3(3); 15041512

Zhang, X., B. Gao, A. E. Creamer, C. Cao, and Y. Li (2017). Adsorption of VOCs onto engineered carbon materials: A review. Journal of Hazardous Materials, 338; 102-123

Zhang, X., X. Lin, Y. He, Y. Chen, X. Luo, and R. Shang (2019). Study on adsorption of tetracycline by $\mathrm{Cu}-$ immobilized alginate adsorbent from water environment. International Journal of Biological Macromolecules, 124; 418428 